Review

\title{
Advances in the Characterization of the Mechanism Underlying Bacterial Canker Development and Tomato Plant Resistance
}

\author{
Yuqing Wang *, Shuozhen Deng, Ziyan Li and Wencai Yang
}

Citation: Wang, Y.; Deng, S.; Li, Z.; Yang, W. Advances in the Characterization of the Mechanism Underlying Bacterial Canker Development and Tomato Plant Resistance. Horticulturae 2022, 8, 209. https://doi.org/10.3390/ horticulturae 8030209

Academic Editor: Yuyang Zhang

Received: 25 December 2021

Accepted: 17 February 2022

Published: 27 February 2022

Publisher's Note: MDPI stays neutral with regard to jurisdictional claims in published maps and institutional affiliations.

Copyright: (C) 2022 by the authors. Licensee MDPI, Basel, Switzerland. This article is an open access article distributed under the terms and conditions of the Creative Commons Attribution (CC BY) license (https:// creativecommons.org/licenses/by/ $4.0 /)$.
Department of Vegetable Science, College of Horticulture, China Agricultural University, Beijing 100193, China; dsz@cau.edu.cn (S.D.); zion820@163.com (Z.L.); yangwencai@cau.edu.cn (W.Y.)

* Correspondence: wyq@cau.edu.cn

\begin{abstract}
Bacterial canker caused by the Gram-positive actinobacterium Clavibacter michiganensis is one of the most serious bacterial diseases of tomatoes, responsible for $10-100 \%$ yield losses worldwide. The pathogen can systemically colonize tomato vascular bundles, leading to wilting, cankers, bird's eye lesions, and plant death. Bactericidal agents are insufficient for managing this disease, because the pathogen can rapidly migrate through the vascular system of plants and induce systemic symptoms. Therefore, the use of resistant cultivars is necessary for controlling this disease. We herein summarize the pathogenicity of $C$. michiganensis in tomato plants and the molecular basis of bacterial canker pathogenesis. Moreover, advances in the characterization of resistance to this pathogen in tomatoes are introduced, and the status of genetics-based research is described. Finally, we propose potential future research on tomato canker resistance. More specifically, there is a need for a thorough analysis of the host-pathogen interaction, the accelerated identification and annotation of resistance genes and molecular mechanisms, the diversification of resistance resources or exhibiting broad-spectrum disease resistance, and the production of novel and effective agents for control or prevention. This review provides researchers with the relevant information for breeding tomato cultivars resistant to bacterial cankers.
\end{abstract}

Keywords: Solanum lycopersicum; bacterial canker; pathogenesis; plant resistance; genetics and breeding

\section{Introduction}

Bacterial cankers of tomatoes is a systemic vascular disease caused by the Grampositive bacterial pathogen Clavibacter michiganensis $(\mathrm{Cm})$ [1,2]. This disease was originally reported in the USA in 1909 [3], and it has now been detected in more than 80 countries in America, Europe, Asia, Africa, and the Oceania, where it has severely decreased tomato production [4-7]. The estimated yield losses caused by this tomato disease vary from $10 \%$ to $100 \%$, depending on the cultural method, location, cultivar, and the host phenological stage during the infection [2,8]. In China, bacterial cankers of tomatoes were first observed in 1954, and the causative pathogen was finally isolated and confirmed as Cm in 1985 [9]. This disease has been reported in most regions of China since then [8]. Researchers and breeders have identified some sources of resistance to bacterial cankers [10-12] but have not developed disease-resistant cultivars or elucidated the genetic mechanisms underlying plant resistance to $\mathrm{Cm}$ yet. This review focuses on the current status of bacterial canker pathogenesis, the identification of resistant tomato germplasm, and the genetic basis of the resistance. Furthermore, we propose future research related to bacterial cankers of tomatoes and provide references potentially useful for identifying resistance genes and breeding bacterial canker-resistant tomatoes.

\section{Symptoms and Control of Bacterial Cankers of Tomatoes}

Bacterial cankers are a systemic vascular disease that can occur at all growth stages of tomatoes. Plants infected by $\mathrm{Cm}$ exhibit various symptoms, depending on plant age, 
cultivar susceptibility, $\mathrm{Cm}$ virulence, and environmental conditions (e.g., temperature and humidity) [13]. When seeds are infected by $\mathrm{Cm}$, the pathogen can directly invade the vascular tissue of tomato seedlings and then induce systemic symptoms that lead to the wilting and withering of plants [14]. When the pathogen infects plants through the stomata and hydathodes, it induces localized leaf symptoms, including marginal leaf necrosis and partial leaflet wilting $[10,13]$. These local symptoms eventually lead to systemic symptoms that result in the withering of whole plants and even death under suitable environmental conditions. During the early infection stage, compound leaves or the whole plant usually exhibit unilateral wilting, or the unilateral leaflet edge appears scorched, initially on the lower side, and then leaves become withered on both sides (Figure 1A,B). As the disease progresses, the other side of compound leaves or the upper leaves also appear wilted, until the whole seedling plant withers (Figure 1C). During the late infection stage, the stem with lesions splits and develops cankers with brown and hollow vascular bundles (Figure 1D). The unilateral wilting of compound leaves and plants in the early-to-mid infection phase is a phenotype that is unique to bacterial cankers of tomatoes, making it useful for distinguishing this disease from other diseases. One hallmark symptom of a $\mathrm{Cm}$ infection of tomato fruit is a bird's eye lesion (Figure 1E), which appears as a white halo on the fruit epidermis surrounding a necrotic lesion $[2,15,16]$. However, bird's eye lesions are not always detectable on infected fruits, which usually have a meshed or marbled outer texture when grown in a greenhouse (Figure 1F) [16].
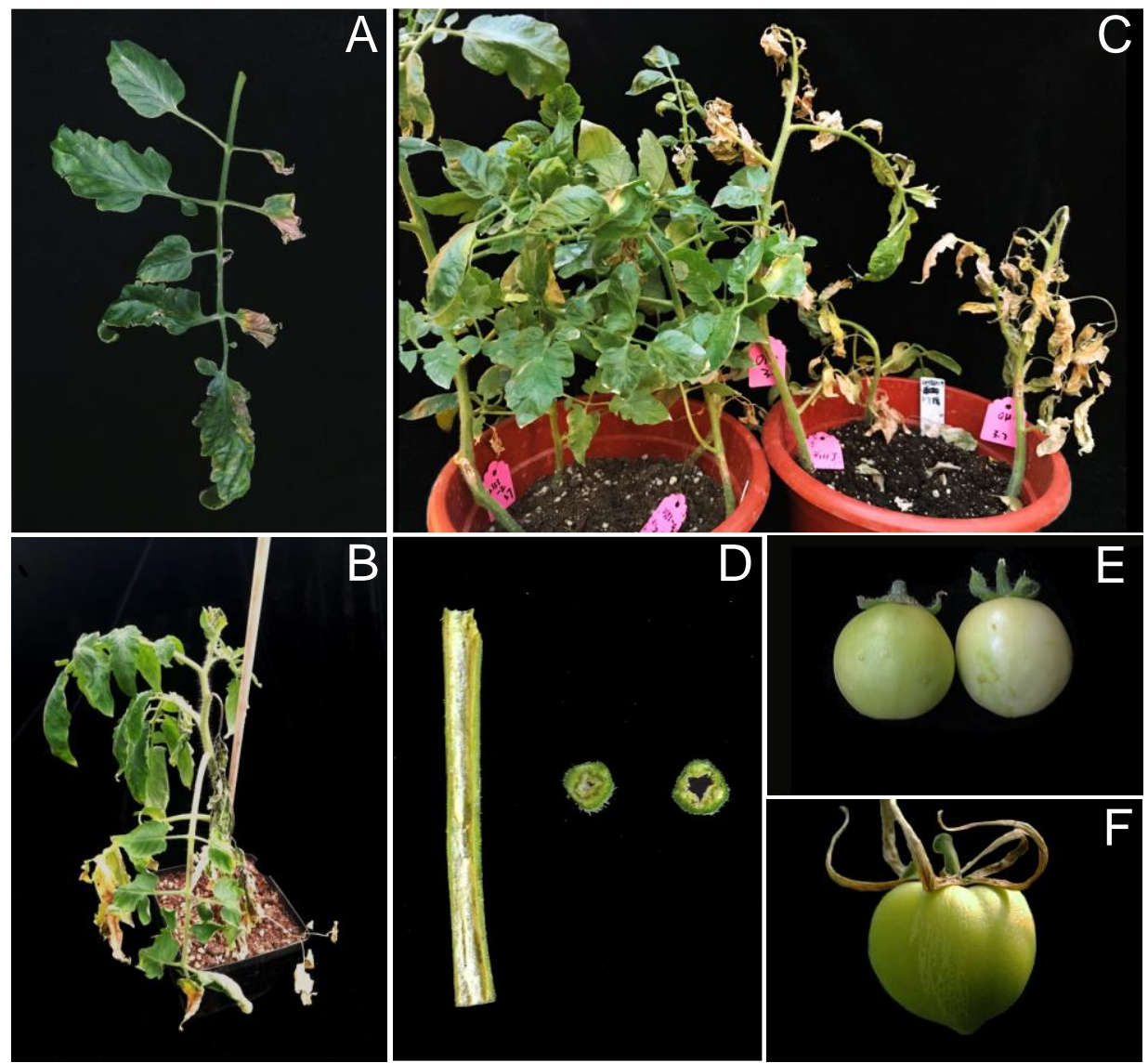

Figure 1. Symptoms of bacterial cankers on diseased tomato plants. (A) Unilateral wilting of a compound leaf. (B) Unilateral wilting of the OH88119 plant at 28 days post-inoculation (dpi). (C) Resistant line IBL2353 plants with mild leaf edges scorched (left), and the wilting plant of susceptible cultivar OH88119 (right) at 35 dpi. (D) Longitudinal section and cross-sections of OH88119 plant stems infected with bacterial cankers at 28 dpi. (E) Bird's eye lesion on artificially inoculated tomato fruits. (F) Meshed texture on the fruit of a naturally infected tomato plant. 
There is a lack of effective methods for controlling bacterial cankers of tomatoes. Chemical, biological, physical, and genetic methods are all part of the current disease control strategy. The first three methods provide limited protection from the disease, but they may be combined with the genetic improvement of tomato disease resistance to effectively and conveniently control bacterial canker outbreaks. Unfortunately, there are no commercial trans-bred cultivars with high levels of resistance to $\mathrm{Cm}$, except for H1301, H1307, and H1418, which are three processing tomato varieties resistant to bacterial cankers, but their use has been restricted by the patent held by Heinz Company [8]. If there is sufficient manpower, producers can increase the resistance of tomato cultivars by grafting them to wild resistant tomato rootstock.

\section{Pathogenicity of $\mathrm{Cm}$}

\subsection{Initial Infection of Plants by $\mathrm{Cm}$}

Earlier research indicated that $\mathrm{Cm}$ enters host tissues only via wounds, cracks, or natural openings, including the stomata and hydathodes [17]. However, vascular wilt pathogens exist in the interior parts of host plants eventually, so the invasion of the vascular system by pathogens involves a complex process [18]. There are no reports describing the invasion process of the $\mathrm{Cm}$ through the outer epidermis openings to specific locations within the epidermis in tomato hosts. An analysis of Burkholderia glumae, which is another bacterial species that infects plant vascular tissues, revealed that epidermal hairs and leaf hairs are the initial colonization sites [19]. Researchers examining the interior of maize leaves infected with another Clavibacter species observed that, after passing through the outer epidermis, C. nebraskensis colonizes leaves through epidermal junctions, cuticle depressions, stomata and the surrounding area, and the trichome base [20].

\subsection{Colonization and Spread of $\mathrm{Cm}$ in Tomato Plant Interior}

The ability of $\mathrm{Cm}$ to spread and densely colonize the host vascular system is critical for systemic infections and symptom development. A previous study demonstrated that vascular pathogens rapidly multiply and invade the root or stem cortex and vascular parenchyma intracellularly after entering through exterior openings, then spread to the xylem vessels that are used for the passive spread to aerial plant parts [18]. On the basis of green fluorescent protein labeling and electron microscopy, researchers confirmed that the Cmm382 strain extensively colonizes the lumen of xylem vessels and preferentially attaches to the spiral secondary wall thickenings of the narrower protoxylem [17]. However, the primary paths used by the bacterium to reach the xylem vessels are mostly unknown.

According to some studies on xylem hydraulics, sap flow rates can be up to $15 \%$ higher in narrow vessels (e.g., protoxylem) than in wide vessels (e.g., metaxylem), making protoxylem vessels ideal conduits for the systemic spread of pathogens [21]. Plant pathogens often must macerate pit membranes and pass them before they can spread from the protoxylem to the metaxylem and nearby parenchyma cells [14,17], but this phenomenon during the spread of $\mathrm{Cm}$ through tomato hosts has not been clearly observed [22]. However, researchers determined that the pathogen can spread after initially colonizing the protoxylem to the metaxylem and nearby parenchyma cells, with a metaxylem bacterial abundance ratio of $7.3 \%$ in a wild resistant accession LA2157, which is significantly lower than the $38.2 \%$ in a susceptible cultivar "Mt. Fresh" [15]. This result explains the inhibited lateral spread of $\mathrm{Cm}$ in wild tomato vascular bundles, which might ultimately lead to milder symptoms in wild S. arcanum LA2157 than in tomato cultivars.

To adapt to the flow of vascular sap, most vascular tissue-colonizing bacterial pathogens use adhesins and EPS to aggregate and form biofilms, as well as Type IV pili for twitching motility [23-26]. However, $\mathrm{Cm}$ lacks canonical pili and chemotaxis- or adhesion-related genes, and it does not require EPS for movement after entering the vascular vessels, unlike other vascular pathogens $[27,28]$. Interestingly, pathogens can form biofilm-like aggregates in xylem vessels and in vitro in the presence of xylem sap but do not form aggregates when 
cultured in nutrient-rich or minimal medium $[15,17,29]$. These results explain why $\mathrm{Cm}$ can aggregate and spread in the xylem of plant hosts.

The results of earlier investigations suggested that $\mathrm{Cm}$ spreads upward in plants, along with the xylem water flow $[12,17,30]$. We previously observed that this pathogen can migrate both downward and upward in the tomato vascular system, but upward migration through xylem is considerably faster than downward movement. Specifically, in the same time period, $\mathrm{Cm}$ can migrate further $(6$ and $12 \mathrm{~cm})$ within a tomato plant and reach a higher population if the stem base is inoculated rather than the stem top ( 3 and $9 \mathrm{~cm}$ ) (Figure 2A,B). Therefore, $\mathrm{Cm}$ can migrate slowly downward in tomato plants via a vascular bundle, which facilitates the systemic diffusion of the pathogen in the host plant. How the pathogen penetrates the sieve element-companion cell complex and moves in the phloem remains unclear.
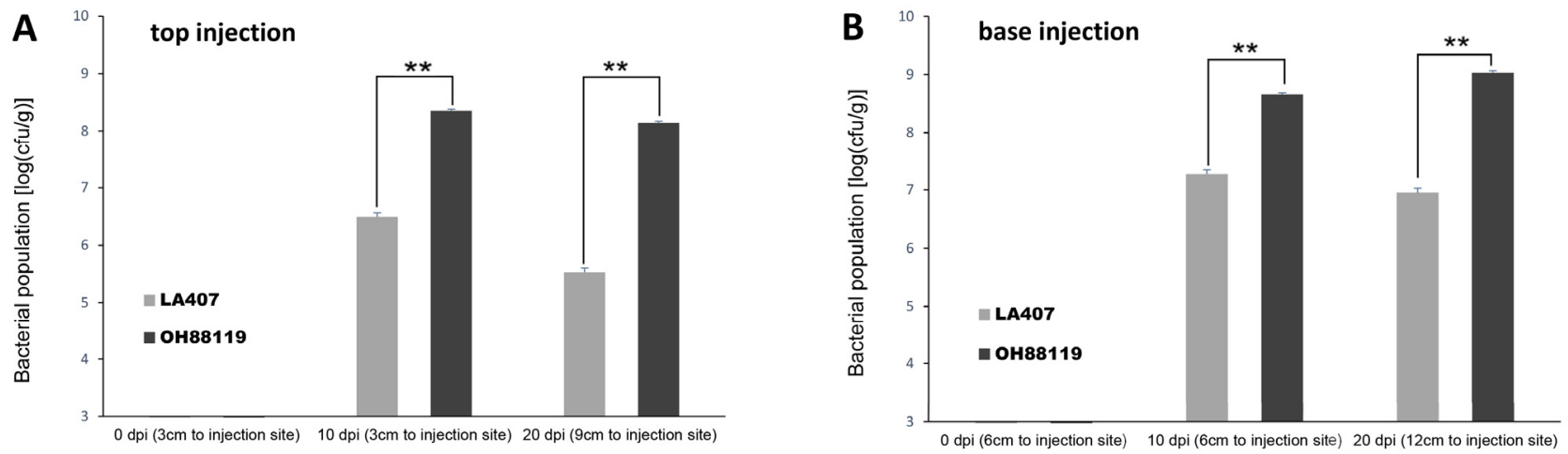

Figure 2. Colonization of Clavibacter michiganensis strain GS12012 at different time points and distances from the inoculation site in tomato plants. Tomato plants at the 5th and 6th true leaf stages were inoculated at the base around the cotyledonary node or top of the stem with GS12012 suspensions. Individual stems ( $0.5 \mathrm{~g})$ were collected and homogenized in 1-mL distilled water plated on LB agar medium after serial dilutions. (A) Upper stem segments of 6 and $12 \mathrm{~cm}$ apart from the inoculation site were collected at 10 and 20 dpi, respectively. (B) Lower stem segments of 3 and $9 \mathrm{~cm}$ apart from the inoculation site were collected at $10 \mathrm{dpi}$ and $20 \mathrm{dpi}$, respectively. Data are presented as the mean of three independent experiments. Asterisks denote significant differences $(p<0.01)$ between the susceptible OH88119 and wild LA407 tomato plants, as determined by Student's $t$-test.

\subsection{Colonization and Spread of $\mathrm{Cm}$ in Tomato Fruit}

Tomato plants are susceptible to $\mathrm{Cm}$ at all growth periods, including the blooming and fruit-setting stages, but there are no published reports regarding the infection of tomato flowers. Moreover, the colonization of tomato fruit by $\mathrm{Cm}$ has been less characterized than the infection of vascular tissues in vegetative organs by this pathogen [31]. Nevertheless, tomato fruit colonization is critical for bacterial canker epidemics, because the bacterium colonizes fruits via systemic infections of the seeds or through the fruit outer surface, which is conducive to pathogen dispersal $[7,31]$. Fruit lesions develop when the pathogen reaches the fruit exterior during the early infection stages [16,31]. Bacteria must invade the pericarp through the outer epidermis to induce lesion formation; after which, they can access fruit xylem vessels for their systemic spread [31]. Thus, before entering fruit xylem vessels, the bacterium must navigate through the outer epidermis, collenchyma, and parenchyma layers. Although it is still unclear how pathogens spread through these tissues, one study involving a fluorescence-based histological examination indicated $\mathrm{Cm}$ can colonize the intracellular space of intact pericarp cells [31]. Intracellular colonization in fruits is rare among plant pathogens, with the exception of Rhodococcus fascians and Streptomyces turgidiscabies [32-34]. Instead, the combined use of carbohydrate-active enzymes (CAZymes) and the exploitation of the host may be more common for the spread of $\mathrm{Cm}$ from the tomato fruit exterior to the fruit xylem [33], but this remains to be experimentally verified. 


\subsection{Plant Wilting Induced by Pathogenic Cm Strains}

There is little consensus regarding how $\mathrm{Cm}$ induces tomato leaf and stem wilting. Previous studies revealed that nonpathogenic strains can spread and colonize the vascular system like pathogenic strains, resulting in similar populations, but they cannot induce wilting $[17,35]$. This finding implies that wilting is not simply induced by $\mathrm{Cm}$ blocking the sap flow in vascular vessels. There is evidence that the inhibited flow in vascular bundles can lead to hydraulic dysfunction in the xylem and then cavitation and embolization of the xylem, which is the main reason for the wilting of plants [36,37]. The effects of $\mathrm{Cm}$ on xylem hydraulics need to be more thoroughly investigated to clarify how unilateral wilting during tomato canker disease development is induced.

\section{Molecular Mechanism Underlying $\mathrm{Cm}$ Pathogenicity}

There has recently been an increase in the number of studies conducted to identify $\mathrm{Cm}$ virulence genes and elucidate the mechanism underlying $\mathrm{Cm}$ pathogenicity. Following the invasion of the tomato plant interior, $\mathrm{Cm}$ can secrete several enzymes that degrade the host cell wall and help the bacterium obtain nutrients as an endophyte [38]. The genes encoding these virulence factors are mainly distributed in two plasmids pCM1 and pCM2, but some factors are present in the chromosomal $\operatorname{chp} / \operatorname{tom} A$ pathogenicity island (PAI) or in other chromosomal regions (Table 1).

\subsection{Virulence Genes in Two Plasmids and PAI}

The celA and pat-1 genes in pCM1 and pCM2, respectively, are the first identified key virulence genes in $\mathrm{Cm}[39,40]$. The $c e l A$ gene encodes a chimeric protein comprising cellulase, carbohydrate-binding, and expansin domains $[28,40]$. The encoded protein is essential for wilt symptom development, because partial or complete deletions of celA in the moderately virulent $\mathrm{Cmm} 101$ strain lacking pCM2 can lead to a complete loss of virulence [40]. Additionally, the transient expression of $c e l A$ in genetically altered and naturally nonpathogenic $\mathrm{Cm}$ strains reportedly restore wilt and canker symptom development [35,40]. Subsequent studies have demonstrated that the cellulase and carbohydrate-binding domains are necessary for strain LMG7333 to be able to induce wilting [41]. Interestingly, expansins were originally characterized in plants as proteins that loosen xyloglucan-cellulose bonds in the cell wall [42,43]. Although CelA contains an expansin domain, CmEXLX1, its contribution to virulence is unclear. Mutations to CmEXLX1 can either decrease the virulence or have no effect on the virulence [40,41]. Mutations to another expansin, CmEXLX2, and the absence of CmEXLX1 may lead to a three-fold increase in wilt symptom severity, as well as an increase in bird's eye lesion severity on fruits [29]. The functions of CmEXLX1 and CmEXLX2 in CelA remain unknown.

The pathogenicity gene pat-1 in plasmid pCM2 encodes a serine protease from chymotrypsin subfamily S1A [12,39]. The results of experiments involving the targeted deletion and complementation of pat-1 in the reference strain NCPPB382 indicated that the encoded enzyme can induce canker symptom development in tomatoes. Whole-genome sequencing analyses detected nine pat-1 homologs in pCM2 ( $p h p A$ and $p h p B)$ and chp/tomA PAI $(\operatorname{chp} A-G)[28,39,44]$. Of these homologs in $\operatorname{ch} p /$ tomA PAI, only $\operatorname{ch} p C$ has been functionally verified in reference strain NCPPB382, wherein it contributes to disease symptom development (e.g., colonization, wilting, and foliar blistering) [6,45]. The ChpG protein is likely involved in plant-pathogen interactions. More specifically, Lu et al. observed that ChpG can trigger a hypersensitive response (HR) in some nonpathogenic Nicotiana species (i.e., N. tabacum, N. sylvestris, N. clevelandii, and N. glutinosa) [46]. Another group reported that the plasmid composition and $\operatorname{ch} p G$ are critical determinants of the virulence of at least three Clavibacter capsici variant groups [47]. Moreover, ChpG can trigger HR in pepper hosts, and $\operatorname{chp} G$ encodes the key virulence factor of different C. capsici strains [47]. 
Table 1. Putative virulence genes and changes in disease phenotypes resulting from mutations to individual genes.

\begin{tabular}{|c|c|c|c|c|}
\hline $\begin{array}{l}\text { Location in } \\
\text { NCPPB382 }\end{array}$ & Gene Ontology & Gene Name & $\begin{array}{l}\text { Mutant Phenotype Changes } \\
\text { in Tomato Tissues }\end{array}$ & References \\
\hline \multirow{3}{*}{ pCM1 plasmid } & $\begin{array}{l}\text { Chymotrypsin-related } \\
\text { serine proteases }\end{array}$ & ppaJ & No report & {$[6]$} \\
\hline & Cellulases & \multirow{2}{*}{$\begin{array}{l}\text { celA } \\
\text { CmEXLX1 } \\
\text { (CelA domain) }\end{array}$} & Avirulent (wilt) & {$[15,35,40,41]$} \\
\hline & Expansins & & Reduced wilt & {$[40,41]$} \\
\hline \multirow{3}{*}{ pCM2 plasmid } & Chymotrypsin & pat-1 & Reduced wilt & {$[40,41]$} \\
\hline & \multirow{2}{*}{ subfamily S1A proteases } & $\operatorname{phpA}$ & No change in wilt & {$[35,39]$} \\
\hline & & $\operatorname{phpB}$ & No change in wilt & [44] \\
\hline \multirow{8}{*}{$\begin{array}{l}\text { pathogenicity } \\
\text { island (PAI) }\end{array}$} & \multirow{4}{*}{$\begin{array}{l}\text { Chymotrypsin subfamily } \\
\text { S1A proteases }\end{array}$} & $\operatorname{chp} A / B / D$ & No report & {$[44]$} \\
\hline & & Chpc & Reduced wilt and blisters & \\
\hline & & $\operatorname{chpE} / F / G$ & No change in wilt and blisters & {$[6,45]$} \\
\hline & & $p p a A / C$ & No change in wilt and blisters & {$[6,45]$} \\
\hline & $\begin{array}{l}\text { Chymotrypsin-related } \\
\text { serine proteases }\end{array}$ & $p p a B 1 / B 2 / D / E$ & No report & {$[6]$} \\
\hline & Subtilase proteases & $s b t B / C$ & Reduced wilt and blisters & \\
\hline & Pectinases & pelA1/A2 & Reduced wilt & [6] \\
\hline & tomatinase & tomA & No change in wilt & [35] \\
\hline \multirow{9}{*}{$\begin{array}{l}\text { chromosome } \\
\text { other regions }\end{array}$} & $\begin{array}{l}\text { Chymotrypsin-related } \\
\text { serine proteases }\end{array}$ & ppaF/G/H/I & No report & [35] \\
\hline & Subtilase proteases & $s b t B / C$ & No change in wilt and blisters & \\
\hline & Cellulases & celB & No change in wilt and blisters & {$[6,41]$} \\
\hline & Xylanases & $x y s A / B$ & No change in wilt and blisters & [6] \\
\hline & Pectinases & pgaA & Reduced blisters, no change in wilt & [6] \\
\hline & Endoglucanases & end $X / Y$ & Reduced blisters, no change in wilt & [35] \\
\hline & Expansins & $\exp A(C m E X L X 2)$ & Increased wilt and bird's eye lesions & {$[40,41]$} \\
\hline & Perforin & perF(perforin) & Reduced blisters, no change in wilt & {$[15,29]$} \\
\hline & Sortase & srt $A($ sortase $)$ & Reduced blisters, no change in wilt & [6] \\
\hline
\end{tabular}

\subsection{Virulence Factors Encoded by Chromosomal Genes}

Using third-generation sequencing technology, researchers have systematically identified many genes encoding secreted CAZymes with putative xylanase, pectinase, and endoglucanase activities on chromosomes but not in the PAI region. Phytopathogenic CAZymes have a central role in plant cell wall degradation and facilitate bacterial colonization and nutrient acquisition [48]. Thapa et al. (2017) sequenced and comparatively analyzed the genomes of $16 \mathrm{Cm}$ strains isolated from infected tomato fields in California, USA, including five Clavibacter strains nonpathogenic to tomatoes, and identified many of the secreted proteins as CAZymes [35]. Glycome profiling revealed that pathogenic $\mathrm{Cm}$ strains, but not endophytic Clavibacter strains, can extensively alter the tomato cell wall composition, and two CAZymes (CelA and PelA1) that are produced by all $\mathrm{Cm}$ strains can increase the pathogenicity [35]. These CAZymes differentially contribute to tomato canker symptom development (Table 1 ). For example, the proteins encoded by the $x y s A / B$ genes have xylanase activity but cannot induce the wilting or blistering of tomato plants [6]. Mutations to pelA1, which encodes a protein with pectinase activity, can lead to significantly decreased pathogenicity [35]. Genes encoding endoglucanases (endX/Y), perforin (perF), and sortase ( $\operatorname{st} A$ ) influence blistering but not wilting. Tomatinase (tomA), which is one of the 13 predicted secreted proteins that are common to all $\mathrm{Cm}$ strains, may contribute to $\mathrm{Cm}$ virulence, but it does not affect wilting [35].

\subsection{Function of Virulence Genes Underlying Cm Pathogenicity}

Functional genetics-based examinations have indicated that reference strain Cmm100, which lacks pCM1 and pCM2, can proliferate to the same population as pathogenic strains, 
but its systemic spread is inhibited and does not induce wilting symptoms in tomato plants. When pCM1 or pCM2 is inserted into Cmm100, the resulting strain restores the ability to colonize hosts and induce wilting, albeit more slowly and less severely than pathogenic strains [17,49]. A transcriptional analysis of wild-type $\mathrm{Cm}$ strain and $\mathrm{Cm}$ lacking both plasmids revealed the interplay of chromosomal and plasmid genes [38,50]. This interplay of plasmids and PAI is thought to be necessary for successful colonization, based on the result that strains of $\mathrm{Cm}$ lacking a $\operatorname{chp} / \operatorname{tom} A$ PAI region or one of the plasmids results in the impaired systemic spread, in vitro aggregation, and virulence of NCPPB382 following the inoculation of the vascular system or the leaf surface $[6,17,51]$. These findings indicate that virulence factors encoded by genes in two plasmids and chp/tomA PAI are probably essential for $\mathrm{Cm}$ pathogenicity.

Studies on the reference strain NCPPB382 have clarified the main genetic basis of $\mathrm{Cm}$ pathogenicity and virulence. This strain and its derivatives are suitable for investigating $\mathrm{Cm}$-host interactions, but recent investigations on the genetic diversity of pathogenic strains revealed that the NCPPB382 genetic repertoire is not necessary for the induction of canker symptoms in tomatoes $[35,51,52]$. The functions of some secreted virulence protein in $\mathrm{Cm}$ remain unknown [7], so we can continue to use the functional genetics, genomics, and omics technologies to obtain insights into the roles of individual genes in the $\mathrm{Cm}$ pathogenicity.

\section{Research Related to Tomato Plant Disease Resistance}

\subsection{Response of Wild Tomato to $\mathrm{Cm}$}

Several studies have confirmed that $C m$ can colonize the vascular and fruit tissues of wild tomato species, but the resulting disease symptoms (e.g., wilting or cankers) are weaker or the bacterial populations are lower than in susceptible tomato cultivars $[10,11,15]$. Our research also demonstrated that the bacterial population in infected wild tomato line LA407 with resistance is lower than that in infected susceptible cultivar OH88119 (Figure 2). Hence, there are differences between resistant and susceptible tomato host cells in terms of their responses to $\mathrm{Cm}$. Additionally, the interactions between the plant host and $\mathrm{Cm}$ pathogen affect bacterial growth in xylem vessels. On the basis of the extent and the speed of $\mathrm{Cm}$ migration in vivo (Figure 2), the colonization of plant hosts by $\mathrm{Cm}$, including the lateral spread of the pathogen, is apparently inhibited in wild tomato plants [21]. This inhibition is probably related to the interaction between the pathogen and the host xylem sap, because some experiments have indicated that the composition of tomato xylem sap affects bacterial growth and biofilm formation [21,53]. In an earlier investigation, the sap extracts from four tomato genotypes were compared in terms of their effects on $\mathrm{Cm}$ growth rates over a 48-h period; the $\mathrm{Cm}$ population was highest for the sap from the most susceptible tomato cultivar [21]. Furthermore, the $C m$ population was always lower for the sap from the wild tomato samples than for the sap from the tomato cultivars. Accordingly, wild resistant tomato plants likely respond to the pathogen by releasing specific substances into the xylem sap and then altering the sap composition to inhibit $\mathrm{Cm}$ pathogen reproduction and spread in plants; another possibility is resistant tomato plants lacking some kind of signals of quorum sensing for priming the virulence of $\mathrm{Cm}$ like the research on Psa in kiwifruit bacterial cankers [54].The xylem sap composition of wild tomato plants may be suboptimal for $\mathrm{Cm}$ growth, leading to decreased in planta growth and symptom development.

The molecular response of tomatoes to $\mathrm{Cm}$ includes the upregulated and downregulated expression of certain genes and proteins. By applying omics-based technology, researchers have identified many tomato genes involved in plant defenses against pathogens with upregulated expression levels during $C m$ infections, including genes related to the production and scavenging of reactive oxygen species, enhanced protein turnover, and hormone (e.g., ethylene and salicylic acid) synthesis and responses [12,38,55,56]. Compared with wild-type plants, ethylene synthesis mutants and ethylene-insensitive $\mathrm{Nr}$ plants inoculated with $\mathrm{Cm}$ reportedly exhibit a delayed onset of disease symptoms (by several days), as well as less severe wilting [55]. These results indicated that tomato host-derived ethylene is a major signal that regulates disease progression in the response to $\mathrm{Cm}$ [55]. 
A recent transcriptome analysis of infected tomato plants revealed the significantly upregulated expression of 122 receptor-like kinases involved in pattern-triggered immunity (PTI) and some transcription factors (e.g., WRKY, NAC, HSF, and CBP60 family members), reflecting their involvement in defense-associated gene expression during tomato- $\mathrm{Cm}$ interactions [56]. Additionally, the production of several proteins related to specific plant defense responses is induced in infected plants [38], including lipoxygenase-1 (LOX1), which is involved in the synthesis of oxylipins or jasmonic acid [57,58], enhanced disease susceptibility 1 (EDS1), which is crucial for basal defense responses against pathogens [59,60], and proteins similar to phytophthora-inhibited protease 1 (PIP1) and PepEST, which are responsive to potential virulence factors [61,62]. The proteome-level analysis of $\mathrm{Cm}$-infected tomatoes revealed a cluster of differentially expressed PR proteins (relative to the corresponding levels in mock-infected controls), including 1,3- $\beta$-glucosidase, endochitinase, cucumisin-like serine protease, osmotin-like proteins, and hevein-like proteins [38]. In addition to known phosphatases and kinases, two phospholipase D signal-transducing proteins reportedly increased in abundance in tomato plants infected with a pathogenic Cm strain [38].

\subsection{Identification and Verification of Resistance-Related Proteins and Enzymes}

The molecular mechanism underlying tomato disease resistance has not been characterized as the molecular basis of bacterial pathogenesis. Previous related studies primarily focused on identifying and functionally annotating individual resistance-related proteins and enzymes in tomatoes. In 2004, researchers used two tomato lines containing resistance loci $R c m 2.0$ and $R c m 5.1$ and a susceptible control line for a comparative proteomic analysis of plants inoculated with $\mathrm{Cm}$, which detected 47 expressed proteins, of which 26 were tomato proteins [63]. Moreover, multiple proteins involved in defense and stress responses, such as remorin, phospholipid glutathione peroxidase, and PR-3, were most abundant in the inoculated line containing $R \mathrm{~cm}$ 2.0. Furthermore, the production of an alcohol dehydrogenase was uniquely upregulated in plants containing $R \mathrm{~cm}$ 5.1, implying that lines with $R \mathrm{~cm} 2.0$ respond uniquely and earlier to a $\mathrm{Cm}$ infection than the other analyzed genotypes [63].

Another earlier investigation demonstrated that phenylalanine ammonia lyase (PAL) activities increase and decrease in resistant and susceptible tomato cultivars, respectively, after an inoculation with $\mathrm{Cm}$. This suggests that PAL activity helps mediate tomato resistance to $\mathrm{Cm}$ based on a correlation with the polyphenol content of the cell wall and involving salicylic biosynthesis [64]. A recent study confirmed that the expression levels of the genes involved in the PAL pathway are upregulated in response to Cm infection [56]. Additionally, the silencing of the gene encoding SUMO E2-conjugating enzyme (SCEI) in plants leads to enhanced $\mathrm{Cm}$ colonization and a substantial increase in damaged tissues (4.5 times on average), reflecting the importance of SCEI for the innate immunity of S. peruvianum accession LA2172 [65].

There are only two reports describing the functional verification of resistance-related proteins via genetic modification. In 2012, Balaji and Smart reported that the overexpression of the snakin-2 peptide and the glycan-rich extensin-like protein adversely affects $\mathrm{Cm}$ invasiveness, suggestive of potential in vivo antibacterial activities [66]. Other researchers observed that bacteriophage CMP1-expressing transgenic tomato plants are symptom-free after $\mathrm{Cm}$ infections, with a significant decrease of the bacterial population in planta [67].

\subsection{Hypersensitive Responses of Other Solanaceae Plants to Cm}

Plants can respond to infections after recognizing specific pathogen effectors and then initiate programmed cell death to block the invasion and spread of pathogens (i.e., HR) [68]. The induction of the tomato $\mathrm{HR}$ by $\mathrm{Cm}$ remains unclear, but there are reports describing the HR in other Solanaceae plants. For example, Chp-G, which is encoded by a member of the pat-1 family of putative serine proteases, triggers the HR in N. tabacum, N. sylvestris, $N$. clevelandii, and N. glutinosa (i.e., non-host plant species). In Nicotiana species, Chp-G is 
recognized by a $S$ genome gene-encoded $R$ protein with an eLRR domain [46]. A recent transcriptome analysis of infected tomato plants revealed that many of the expressed genes were annotated with Gene Ontology terms associated with plant defense responses to pathogens (e.g., plant-type hypersensitive response; GO:0009626) [56]. These research results suggest identifying more $\mathrm{R}$ proteins or HR-related proteins in tomatoes or other Solanaceae crops, and then, transforming tomato cultivars with the corresponding genes may be an effective strategy for enhancing the resistance of tomato plants to $\mathrm{Cm}$. There is currently a lack of cloned bacterial canker resistance genes from tomato species. Thus, research on the mechanism mediating the resistance of tomatoes to bacterial cankers must be accelerated and broadened.

\section{Genetics-Based Research and Breeding to Enhance Resistance to Bacterial Canker 6.1. Identification of Resistant Tomato Accessions}

Tomato accessions vary in their susceptibility to $\mathrm{Cm}$, with most resistant tomato lines identified as wild-type S. pimpinellifolium, S. peruvianum, S. habrochaites, and S. parviflorum or cultivars derived from these lines (Table 2). An S. pimpinellifolium accession resistant to $\mathrm{Cm}$ was first identified in 1934, whereas the Cm-resistant materials S. habrochaites PI251305 and Homestead and Heinz 1350 (cultivars) were detected much later [69,70]. Another research group determined that $S$. habrochaites LA407 is resistant to $C m$, which is consistent with our observations of the inoculated plants (Figure 2) [11]. In an earlier investigation, S. peruvianum PI127829 and LA385 and S. arcanum LA2157 were detected as the most resistant accessions to $\mathrm{Cm}$, although $S$. habrochaites LA407 and cultivar IRAT L3 were also relatively resistant to the pathogen (relative to 24 wild-type lines and one cultivar) [10]. In subsequent studies, some cultivars (e.g., Bulgaria 12, Heinz 2990, and Okitsu Sozai 1-20) derived from crossing with $S$. pimpinellifolium as parents were observed to exhibit a certain degree of bacterial canker resistance [2]. To date, S. arcanum LA2157 and S. habrochaites LA407 are two of the most studied $\mathrm{Cm}$-resistant accessions, and their resistance-related characteristics have been reported [2,8,63,71,72].

Selecting an appropriate inoculation method is important for assessing plant disease resistance. High-pressure spray applications and stab inoculations are currently the common methods used in the artificial inoculation of tomato plants for resistance identification $[10,11,15]$. Our work demonstrated that injecting the stem base around the cotyledonary node using a syringe at the five- or six-leaf stage can induce typical tomato canker symptoms and minimize the damage to plants. This method is conducive for subsequent phenotypic analyses, making it suitable for identifying new sources of resistance and for breeding. The severity of bacterial canker infections is generally assessed using the individual disease rating score scale (0-5). A score of 0 reflects a lack of symptoms, whereas a score of 1 indicates the presence of very mild symptoms. On the basis of the severity of wilting and canker development, the score is increased by 0.5 or 1 . Plants with severe necrotic lesions, wilting, and canker development will have a score of 4.5 , whereas the highest score is reserved for dead plants [11]. 
Table 2. Sources of resistance to Clavibacter michiganensis and their genetic interactions in Solanum species.

\begin{tabular}{|c|c|c|c|}
\hline Resistance Source & Population Type & Gene Interactions & References \\
\hline S. lycopersicum & Introgression lines Bulgaria 12 & Polygenic and horizontal type resistance & [8] \\
\hline S. lycopersicum & Bulgaria $12 \mathrm{~F}_{2}$ and backcross & $\begin{array}{l}\text { Incomplete dominant genes with one to } \\
\text { four major genes }\end{array}$ & {$[2]$} \\
\hline S. lycopersicum & $\begin{array}{l}\text { Hawaii } 7998 \text { and Irat-L3 } \\
\text { RIL population }\end{array}$ & $\begin{array}{l}\text { Complementary genes with } \\
\text { transgressive segregation }\end{array}$ & {$[2,4]$} \\
\hline S. pimpinellifolium & $\begin{array}{l}\text { Homestead, Heinz } 1350 \\
\text { Utah } 737 \text { and Utah } 20\end{array}$ & Polygenic and horizontal type resistance & {$[69,70]$} \\
\hline S. pimpinellifolium & $\begin{array}{l}\mathrm{F}_{2} \text { and backcross of } \\
\text { interspecific cross }\end{array}$ & 4 to 11 with presence of modifying genes & [2] \\
\hline S. pimpinellifolium & PI344102 and PI344103 & 4 genes & {$[4,8]$} \\
\hline S. peruvianum var. humifusum & $\begin{array}{l}\text { Cm } 180 \text { (S. peruvianum var. } \\
\text { humifusum } \times(\text { S. lycopersicum } \\
\times \text { S. chilense LA } 460)) \mathrm{F}_{2} \text { and } \\
\text { backcross population }\end{array}$ & A single dominant gene on $\mathrm{Chr} 4$ & [2] \\
\hline S. arcanum & $\begin{array}{l}\mathrm{LA} 2157 \mathrm{~F}_{2} \text { and backcross of } \\
\text { intraspecific cross }\end{array}$ & $\begin{array}{l}\text { Two to three genes with } \\
\text { recessive inheritance }\end{array}$ & [72] \\
\hline S. arcanum & $\begin{array}{l}\text { LA2157 Backcross of } \\
\text { intraspecific cross }\end{array}$ & 5 regions on chromosomes $1,6,7,8$, and 10 & [73] \\
\hline S. arcanum & $\begin{array}{l}\text { LA2157 } \mathrm{F}_{2} \text { population of } \\
\text { interspecific cross }\end{array}$ & $\begin{array}{l}3 \text { QTLs on chromosomes 5, 7, and } 9 \\
\text { additive interactions of QTLs }\end{array}$ & [72] \\
\hline S. habrochaites & $\begin{array}{l}\text { LA } 407 \text { Inbred backcross lines } \\
\text { of interspecific cross }\end{array}$ & $\begin{array}{l}2 \text { QTLs on chromosome } 2 \text { and } 5 \text { additive } \\
\text { interactions of QTLs }\end{array}$ & {$[63,71]$} \\
\hline S. habrochaites & Highlander and Campbell & Polygenic and horizontal type resistance & {$[69,70]$} \\
\hline S. habrochaites & PI251305 & $1-3$ genes & {$[69,70]$} \\
\hline S. habrochaites & Okitsu Sozai 1-20 & One major gene plus modifier genes & [8] \\
\hline
\end{tabular}

\subsection{Breeding of Disease-Resistant Tomato}

The simplest and most convenient method for introducing the disease-resistant trait into tomato cultivars involves a cross with a resistant material. For example, Solanum nigrum was used as the resistant parent in a cross that resulted in disease-resistant tomato line 98-1; the progeny plants were moderately resistant to bacterial cankers but also had unfavorable traits of the wild parent (i.e., very small fruits and short stature) [74]. Another group crossed a cultivated tomato accession with $S$. habrochaites LA407, which resulted in progeny plants that produced very small fruits or exhibited parthenocarpy [4]. These findings indicate that the resistance locus in wild tomatoes is closely linked with some unfavorable agronomic traits. Hence, bacterial canker-resistant cultivars can be developed via marker-assisted selection, which can minimize the undesirable linkage drag from wild relatives [8]. Molecular markers linked to the QTLs conferring resistance to bacterial cankers were mainly identified in the wild accessions $S$. arcanum LA2157 and S. habrochaites LA407. The markers in LA2157 were mainly RFLPs, whereas the markers in LA407 were mainly CAPS and Indels [71,72]. However, because the markers are weakly linked to resistance, they cannot be used directly for tomato breeding. Instead, the QTLs for disease resistance must be finely mapped or cloned to develop molecular markers tightly linked to the resistance or functional markers of genes/QTLs. Future studies will need to generate easy-to-use and accurate molecular markers (e.g., Indels or SNPs) relevant for breeding bacterial canker-resistant tomato lines.

Another option involves the cloning of resistance genes and then incorporating them into tomato cultivars. On the basis of genetic analyses of the backcross progeny population and the $\mathrm{F}_{2}$ population derived from a cross between resistant and susceptible parents, researchers suggested that bacterial canker resistance is quantitatively inherited and controlled by polygenic loci [63,71-73]. Through an intraspecific cross, five resistance-related QTLs in S. arcanum LA2157 were detected on chromosomes 1, 6, 7, 8, and 10 [73]. Another group used LA2157 for an interspecific cross with $S$. lycopersicum, which led to the 
identification of three QTLs on chromosomes 5, 7, and 9, all of which were additive and co-dominant, but the main QTL was on chromosome 7 [72]. Another well-characterized source of resistance (S. habrochaites LA407) has been subjected to comprehensive genetic analyses $[63,71]$. An examination of a backcross population indicated that the resistance of LA407 was due to several QTLs, including two major resistance QTLs [63]. One QTL (Rcm 2.0) on chromosome 2 was mapped to a 4.4-cM interval and accounted for $25.7-34.0 \%$ of the phenotypic variation in disease severity. Another QTL ( $R \mathrm{~cm}$ 5.1) on chromosome 5 was mapped to a 2.2-cM interval and accounted for $25.8-27.9 \%$ of the observed phenotypic variation. When both QTLs were homozygous and present in the same genetic background, they controlled $68.8-79.9 \%$ of the variation in $\mathrm{Cm}$ resistance [63,71]. Additionally, they suggested the resistance was determined by additive gene activities and additive-by-additive epistatic interactions [63]. However, $\mathrm{R}$ genes associated with $\mathrm{Cm}$ resistance have yet to be identified. An integrated analysis of the results of previous investigations revealed the complexity in the genetic mechanism underlying the resistance of tomato plants to $\mathrm{Cm}$, which has limited the cloning and verification of key major genes. Researchers will need to continue to try to clone and identify resistance genes for the breeding of resistant tomato cultivars.

\section{Future Directions and Prospects}

It has been more than 100 years since the first report of bacterial cankers of tomatoes, but there is still no commercial cultivar with substantial levels of resistance to the pathogen causing this disease. On the basis of what is currently known about $\mathrm{Cm}$ pathogenicity and the resistance of tomato hosts and the relative lack of efficacy of the available chemical and biological control agents, we propose four future research directions that may eventually lead to effective and economically sustainable methods for controlling bacterial cankers in tomato crops.

\subsection{Comprehensively Characterize the Interaction between Tomato Host Plants and Pathogenic Cm Strains}

The diversity in the effects of a single pathogen on various host plants indicates the susceptibility or resistance of host plants to a particular pathogen and mainly depends on the plant-pathogen interaction. A comprehensive characterization of the interaction between $\mathrm{Cm}$ and tomato plants will likely lead to improved disease management practices that minimize the pathogen pathogenicity or host compatibility. Research on the reference strain NCPPB382 has expanded our understanding of Cm biology and virulence [12]. However, relatively little is known about the roles of each virulence factor during infection or the associated disease symptoms. Virulence genes that induce different symptoms in stem, leaf, and fruit tissues will need to be identified through a multifaceted approach involving microscopy, multi-omics experiments, mutational studies, and immunofluorescence analyses. Notably, there has been almost no research on the virulence factors contributing to the development of bird's eye lesions or the initial bacterial colonization of the phyllosphere. First, we will need to identify the virulence factors associated with fruit lesions. These virulence genes will then need to be mutated, with the resulting mutants used for a detailed ultrastructural examination of lesion development and pathogen invasion. The in situ subcellular localization of $\mathrm{Cm}$ pathogenicity-related proteins and multi-omics analyses of bacterial mutants in the susceptible tissues of diverse tomato hosts will provide additional insights into tomato- $\mathrm{Cm}$ interactions and bacterial canker disease development. Additionally, a thorough analysis of the host responses to $\mathrm{Cm}$, as well as the associated signaling pathways, which will vary among tomato species and will provide insights into the resistance of these plants. Investigating tomato- $\mathrm{C} m$ interactions may also lead to the identification of the genes involved in plant responses to various virulence factors. 


\subsection{Accelerate the Identification of Resistance Genes and the Elucidation of the Molecular Mechanism Underlying Tomato Disease Resistance}

Researchers initially determined that the resistance of tomatoes to bacterial cankers is controlled by polygenic loci in 1999 [72], but we still do not know whether the resistance factors are antimicrobial substances induced by signal transduction and/or morphological barriers, including rigid vascular tissues. Moreover, the polygenic locus has not been mapped, and the genes have not been cloned. Exploiting the resistance genes in wild tomato lines will require the acceleration of research combining multi-omics sequencing technologies. Two recent transcriptome analyses of $\mathrm{Cm}$-infected tomatoes have been reported, one of which focused on the gene expression changes in tomato cultivar Money maker at $0,1,3$, and $6 \mathrm{dpi}$, whereas the other compared the resistant wild line LA 2157 and the cultivar Ailsa Craig at 0, 8, and $24 \mathrm{~h}$ post-inoculation (hpi). Both studies identified many candidate resistance-related genes, including those encoding polyphenol oxidase $\mathrm{E}$, diacyl glycerol kinase, TOM1-like protein 6, and an ankyrin repeat-containing protein, as well as SILYK1/Bti9, SILYK4/9, SIEDS1/S5, and SIPAD4 [56,75]. Next, researchers should adopt transgenic or gene-editing technology to screen and functionally characterize candidate genes.

Plant resistance to pathogens involves a network of signaling pathways and crosstalk between and within the host and the pathogen. Therefore, in addition to cloning individual resistance genes in wild species, the systemic resistance mechanism should be clarified to optimize the utility of $\mathrm{Cm}$-resistant germplasm, as well as the transfer of resistance to susceptible cultivars. Since tomato cell responses to $\mathrm{Cm}$ were revealed to be associated with PTI [57], we need to confirm whether tomato responses to $\mathrm{Cm}$ initiate PTI and elucidate the related signaling pathway to clarify the molecular basis of the resistance to $\mathrm{Cm}$. Although the required research may be time-consuming, it will likely be worthwhile.

\subsection{Broaden the Resistance Resources or Introduce Broad-Spectrum Resistance into Tomato}

Plant breeders develop disease-resistant cultivars using a variety of approaches, among which, the most common is the use of dominant $\mathrm{R}$ genes, which follow gene-for-gene relationships. Although tomato $\mathrm{R}$ genes involved in the $\mathrm{Cm}$ pathosystem have not been identified, an examination of another Solanaceae crop species (i.e., Nicotiana species) revealed its $H R$ to $\mathrm{Cm}$ and resulted in the identification of an $\mathrm{R}$ protein with the eLRR domain [46]. In the future, it may be possible to detect additional $\mathrm{R}$ genes responsive to $\mathrm{Cm}$ in Nicotiana or other species. These genes may then be transferred into tomato cultivars, which should then be evaluated regarding their resistance to $\mathrm{Cm}$.

Researchers recently demonstrated that altering a plant gene (susceptibility gene) that facilitates compatibility may lead to broad-spectrum and durable stress resistance in plants [76]. In contrast to the gene-for-gene model of R genes, the susceptibility (S) genes follow an inverse gene-for-gene model, where the virulence/toxin gene of the pathogen can cause infections only when the host carries a dominant $S$ allele [77]. Therefore, editing the $S$ genes in tomato cultivars to make them unrecognizable to the pathogens is an option worth exploring. Recent reports indicated that SWEET (Sugars Will Eventually be Exported Transporter) genes function as $S$ genes in several pathosystems, including that of tomato gray mold disease [78]. SWEET genes have been identified in approximately 30 plant species [76], including 31 genes in tomatoes [79]. Additionally, SISWEET15 expression is reportedly induced by $\mathrm{B}$. cinerea at $16 \mathrm{hpi}$, which may provide the fungus with sugars to promote hyphal growth in the pre-necrotic stage of the infection of tomato plants [78]. Thus, the key $\mathrm{S}$ genes in tomatoes for $\mathrm{Cm}$ should be identified and then used to obtain diseaseresistant tomato lines through three methods. First, mutagenesis-based experiments can introduce sequence variations in S promoters that will prevent the binding of TALES to EBEs, thereby preventing the activation of $S$ genes. Second, genome-editing techniques can be used to modify $S$ genes to generate TALEN-mediated mutations or CRISPR/Cas9mediated mutations. Third, resistant lines may be developed via the artificial miRNAmediated knockdown of $S$ genes. These three approaches have been used for other crops, 
especially rice, suggesting they will be applicable to tomatoes. If SISWEET genes or other $S$ genes are confirmed to participate in the interaction between tomatoes and $C m$, it may enable the introduction of broad-spectrum bacterial resistance in tomatoes.

\subsection{Design Novel Effective Agents for the Comprehensive Control of Bacterial Canker of Tomato}

Along with the fundamental research on pathogenicity and host-pathogen interactions, applied research should be conducted to improve the current bacterial canker control strategies in the greenhouse and field. Traditional copper treatments cannot effectively control the pathogen and have been associated with phytotoxic effects [80]. Therefore, novel organic or biological compounds that can effectively control $\mathrm{Cm}$ in an environmentally friendly manner must be developed. Some organic antimicrobial substances, including lysozyme, fragarin, bacteriophage endolysins, and plant essential oils, can restrict the bacterial spread to some extent [2]. Thus, researchers should continue to extract substances from certain plants or Lactobacillus or fungi with inhibitory effects on $\mathrm{Cm}$ growth. The efficacy of these compounds for controlling $\mathrm{Cm}$ in tomato plants will need to be assessed before the most appropriate compound is developed into a biological product and tested using a variety of strains. Additionally, we can adopt another method of controlling $\mathrm{Cm}$ in host plants that involves the chemical activation of the plant defense system. Chemicals that are known to activate plant resistance include salicylic acid, jasmonic acid, DL- $\beta$ aminobutyric acid, potassium salts, 2,6-dichloroisonicotinic acid, acibenzolar-S-methyl, and specific volatiles such as nitric oxide and ethylene [81,82]. Two recent reports described the inhibitory effects of ethylene and salicylic acid on $\mathrm{Cm}$ growth and symptom development $[55,56]$. Characterizing the resistance mechanism mediated by ethylene and SA may facilitate the development of specific chemical agents that can be exogenously applied to increase tomato plant resistance to pathogens. This method includes detecting and identifying BVOCs from volatile emissions induced by plant hormones and design into biocontrol agents. Furthermore, there is a need for highly sensitive and cost-effective assays for detecting pathogenic $\mathrm{Cm}$ in seed lots to exclude the pathogen, because the population threshold for disease induction is as low as 100 CFU per seed [83]. The development of gene-targeted drug technology and the identification of many key virulence factors may eventually lead to the biotechnology-based targeting of $\mathrm{Cm}$ virulence-related proteins and new bioagents.

Finally, comprehensive and effective disease management strategies must be accompanied by the breeding of new tomato lines exhibiting improved resistance or tolerance to bacterial cankers. The development of novel agents combined with the output of the proposed future research will result in new or improved disease management strategies and resistant commercial cultivars for controlling bacterial cankers of tomatoes.

Author Contributions: Conceptualization, Y.W. and W.Y.; literature collection, S.D. and Z.L.; writingoriginal draft preparation, S.D. and Y.W.; writing-review and editing, W.Y.; supervision, Y.W.; funding acquisition, Y.W. All authors have read and agreed to the published version of the manuscript.

Funding: This research was funded by the National Natural Science Foundation of China, grant number 31501753.

Institutional Review Board Statement: Not applicable.

Informed Consent Statement: Not applicable.

Data Availability Statement: Not applicable.

Acknowledgments: The authors gratefully acknowledge Luo Laixin from the Department of Plant Pathology at the China Agricultural University for providing bacterial canker pathogen strain GS12102.

Conflicts of Interest: The authors declare no conflict of interest. 


\section{References}

1. Li, X.; Tambong, J.; Yuan, K.X.; Chen, W.; Xu, H.; Levesque, C.A.; De Boer, S.H. Re-classification of Clavibacter michiganensis subspecies on the basis of whole-genome and multi-locus sequence analyses. Int. J. Syst. Evol. Microbiol. 2018, 68, 234-240. [CrossRef] [PubMed]

2. Sen, Y.; Van der Wolf, J.; Visser, R.G.; Van Heusden, S. Bacterial canker of tomato: Current knowledge of detection, management, resistance, and interactions. Plant Dis. 2015, 99, 4-13. [CrossRef] [PubMed]

3. Smith, E.F. A new tomato disease of economic importance. Science 1910, 31, 794-796.

4. Yang, W.C.; Francis, D.M. Genetics and breeding for resistance to bacterial diseases in tomato: Prospects for marker assisted selection. In Genetic Improvement of Solanaceous Crops, 1. Tomato; Razdan, M.K., Mattoo, A.K., Eds.; Science Publishers: Enfield, NH, USA, 2007; pp. 379-419.

5. EPPO. Distribution of Clavibacter michiganesis subsp. michiganesis 2016. Available online: https://gd.eppo.int/taxon/CORBMI/ distribution (accessed on 8 February 2022).

6. Chalupowicz, L.; Barash, I.; Reuven, M.; Dror, O.; Sharabani, G.; Gartemann, K.H.; Eichenlaub, R.; Sessa, G.; Manulis-Sasson, S. Differential contribution of Clavibacter michiganensis subsp. michiganensis virulence factors to systemic and local infection in tomato. Mol. Plant Pathol. 2017, 18, 336-346. [CrossRef] [PubMed]

7. Peritore-Galve, F.C.; Tancos, M.A.; Smart, C.D. Bacterial canker of tomato: Revisiting a global and economically damaging seedborne pathogen. Plant Dis. 2021, 105, 1581-1595. [CrossRef]

8. Wang, Y.Q.; Zhang, Y.X.; Gao, Z.P.; Yang, W.C. Breeding for resistance to tomato bacterial diseases in China: Challenges and prospects. Hortic Plant J. 2018, 4, 193-207. [CrossRef]

9. Liu, P.H.; Zhang, L.; Li, M.Y. Occurrence of tomato bacterial canker in Beijing. Plant Protction 1986, 12, 32-33. (In Chinese)

10. Sen, Y.; Feng, Z.; Vandenbroucke, H.; Van der Wolf, J.; Visser, R.G.; Van Heusden, A.W. Screening for new sources of resistance to Clavibacter michiganensis subsp. michiganensis (Cmm) in tomato. Euphytica 2013, 190, 309-317. [CrossRef]

11. Francis, D.M.; Kabelka, E.; Bell, J.; Franchino, B.; Clair, D.S. Resistance to bacterial canker in tomato (Lycopersicon hirsutum LA407) and its progeny derived from crosses to L. esculentum. Plant Dis. 2001, 85, 1171-1176. [CrossRef]

12. Nandi, M.; Macdonald, J.; Liu, P.; Weselowski, B.; Yuan, Z.P. Clavibacter michiganensis ssp. michiganensis: Bacterial canker of tomato, molecular interactions and disease management. Mol. Plant Pathol. 2018, 19, 2036-2050. [CrossRef]

13. Carlton, W.M.; Braun, E.J.; Gleason, M.L. Ingress of Clavibacter michiganensis subsp. michiganensis into tomato leaves through hydathodes. Phytopathology 1998, 88, 525-529. [CrossRef] [PubMed]

14. Xu, X.; Rajashekara, G.; Paul, P.A.; Miller, S.A. Colonization of tomato seedlings by bioluminescent Clavibacter michiganensis subsp. michiganensis under different humidity regimes. Phytopathology 2012, 102, 177-184. [CrossRef] [PubMed]

15. Peritore-Galve, F.C.; Miller, C. and Smart, C.D. Characterizing colonization patterns of Clavibacter michiganensis during infection of tolerant wild Solanum species. Phytopathology 2020, 110, 574-581. [CrossRef] [PubMed]

16. Mekina-Mora, C.M.; Hausbeck, M.K.; Fulbright, D.W. Bird's eye lesions of tomato fruit produced by aerosol and direct application of Clavibacter michiganensis subsp. michiganensis. Plant Dis. 2001, 85, 88-91. [CrossRef]

17. Chalupowicz, L.; Zellermann, E.M.; Fluegel, M.; Dror, O.; Eichenlaub, R.; Gartemann, K.H.; Savidor, A.; Sessa, G.; Iraki, N.; Barash, I. Colonization and movement of GFP-labeled Clavibacter michiganensis subsp. michiganensis during tomato infection. Phytopathology 2012, 102, 23-31. [CrossRef]

18. Yadeta, K.; Thomma, B. The xylem as battleground for plant hosts and vascular wilt pathogens. Front. Plant Sci. 2013, 4, 97. [CrossRef]

19. Li, L.; Wang, L.; Liu, L.; Hou, Y.; Huang, S.; Li, Q. Infection process of Burkholderia glumae in rice spikelets. J. Phytopathol. 2017, 165, 123-130. [CrossRef]

20. Mallowa, S.O.; Mbofung, G.Y.; Eggenberger, S.K.; Den Adel, R.L.; Scheiding, S.R.; Robertson, A.E. Infection of maize by Clavibacter michiganensis subsp. nebraskensis does not require severe wounding. Plant Dis. 2016, 100, 724-731. [CrossRef]

21. Bouda, M.; Windt, C.W.; McElrone, A.J.; Brodersen, C.R. In vivo pressure gradient heterogeneity increases flow contribution of small diameter vessels in grapevine. Nat. Commun. 2019, 10,1-10. [CrossRef]

22. Utsuzawa, S.; Fukuda, K.; Sakaue, D. Use of magnetic resonance microscopy for the nondestructive observation of xylem cavitation caused by pine wilt disease. Phytopathology 2005, 95, 737-743. [CrossRef] [PubMed]

23. Lowe-Power, T.M.; Khokhani, D.; Allen, C. How Ralstonia solanacearum exploits and thrives in the flowing plant xylem environment. Trends Microbiol. 2018, 26, 929-942. [CrossRef] [PubMed]

24. Meng, Y.; Li, Y.; Galvavni, C.D.; Turner, J.N.; Burr, T.J.; Hoch, H.C. Upstream migration of Xylella fastidiosa via pilus-driven twitching motility. J. Bacteriol. 2005, 187, 5560-5567. [CrossRef] [PubMed]

25. De La Fuente, L.; Burr, T.J.; Hoch, H.C. Mutations in type I and type IV pilus biosynthetic genes affect twitching motility rates in Xylella fastidiosa. J. Bacteriol. 2007, 189, 7507-7510. [CrossRef]

26. Rapicavoli, J.; Ingel, B.; Blanco-Ulate, B.; Cantu, D.; Roper, C. Xylella fastidiosa: An examination of a re-emerging plant pathogen Mol. Plant Pathol. 2018, 19, 786-800. [CrossRef]

27. Bermpohl, A.; Dreier, J.; Bahro, R.; Eichenlaub, R. Exopolysaccharides in the pathogenic interaction of Clavibacter michiganensis subsp. michiganensis with tomato plants. Microbiol. Res. 1996, 151, 391-399. [CrossRef] 
28. Gartemann, K.H.; Abt, B.; Bekel, T.; Burger, A.; Engemann, J.; Flugel, M.; Gaigalat, L.; Goesmann, A.; Gräfen, I.; Kalinowski, J.; et al. The genome sequence of the tomato-pathogenic actinomycete Clavibacter michiganensis subsp. michiganensis NCPPB382 reveals a large island involved in pathogenicity. J. Bacteriol. 2008, 190, 2138-2149. [CrossRef]

29. Tancos, M.A.; Lowe-Power, T.M.; Peritore-Galve, F.C.; Tran, T.M.; Allen, C.; Smart, C.D. Plant-like bacterial expansins play contrasting roles in two tomato vascular pathogens. Mol. Plant Pathol. 2018, 19, 1210-1221. [CrossRef]

30. Eichenlaub, R.; Gartemann, K.H.; Burger, A. Clavibacter michiganensis, a group of gram-positive phytopathogenic bacteria. In Plant-Associated Bacteria; Springer: Dordrecht, The Netherlands, 2006; pp. 385-421.

31. Tancos, M.A.; Chalupowicz, L.; Barash, I.; Manulis-Sasson, S.; Smart, C.D. Tomato fruit and seed colonization by Clavibacter michiganensis subsp. michiganensis through external and internal routes. Appl. Environ. Microbiol. 2013, 79, 6948-6957. [CrossRef]

32. Cornelis, K.; Ritsema, T.; Nijsse, J.; Holsters, M.; Goethals, K.; Jaziri, M. The plant pathogen Rhodococcus fascians colonizes the exterior and interior of the aerial parts of plants. Mol. Plant. Microbe. Interact. 2001, 14, 599-608. [CrossRef]

33. Hogenhout, S.A.; Loria, R. Virulence mechanisms of Gram-positive plant pathogenic bacteria. Curr. Opin. Plant Biol. 2008, 11, 449-456. [CrossRef]

34. Van der Meij, A.; Willemse, J.; Schneijderberg, M.A.; Geurts, R.; Raaijmakers, J.M.; Van Wezel, G.P. Inter- and intracellular colonization of Arabidopsis roots by endophytic actinobacteria and the impact of plant hormones on their antimicrobial activity. Antonie Van Leeuwenhoek. 2018, 111, 679-690. [CrossRef]

35. Thapa, S.P.; Pattathil, S.; Hahn, M.G.; Jacques, M.A.; Gilbertson, R.L.; Coaker, G. Genomic analysis of Clavibacter michiganensis reveals insight into virulence strategies and genetic diversity of a Gram-positive bacterial pathogen. Mol. Plant Microbe Interact. 2017, 30, 786-802. [CrossRef] [PubMed]

36. Pérez-Donoso, A.G.; Greve, L.C.; Walton, J.H.; Shackel, K.A.; Labavitch, J.M. Xylella fastidiosa infection and ethylene exposure result in xylem and water movement disruption in grapevine shoots. Plant Physiol. 2007, 143, 1024-1036. [CrossRef] [PubMed]

37. Venturas, M.D.; Sperry, J.S.; Hacke, U.G. Plant xylem hydraulics: What we understand, current research, and future challenges. J. Integr. Plant Biol. 2017, 59, 356-389. [CrossRef]

38. Savidor, A.; Teper, D.; Gartemann, K.H.; Eichenlaub, R.; Chalupowicz, L.; Manulis-Sasson, S.; Barash, I.; Tews, H.; Mayer, K.; Giannone, R.J.; et al. The Clavibacter michiganensis subsp. michiganensis-tomato interactome reveals perception of pathogen by the host and suggests mechanisms of infection. J. Proteome Res. 2012, 11, 736-750. [CrossRef] [PubMed]

39. Dreier, J.; Meletzus, D.; Eichenlaub, R. Characterization of the plasmid encoded virulence region pat- 1 of the phytopathogenic Clavibacter michiganensis subsp. michiganensis. Mol. Plant Microbe Interact. 1997, 10, 195-206. [CrossRef] [PubMed]

40. Jahr, H.; Dreier, J.; Meletzus, D.; Bahro, R.; Eichenlaub, R. The endo-beta-1, 4-glucanase CelA of Clavibacter michiganensis subsp. michiganensis is a pathogenicity determinant required for induction of bacterial wilt of tomato. Mol. Plant Microbe Interact. 2000 13, 703-714. [CrossRef]

41. Hwang, I.S.; Oh, E.J.; Lee, H.B.; Oh, C.S. Functional characterization of two cellulase genes in the Gram-positive pathogenic bacterium Clavibacter michiganensis for wilting in tomato. Mol. Plant-Microbe Interact. 2019, 32, 491-501. [CrossRef]

42. Cosgrove, D.J. Loosening of plant cell walls by expansins. Nature 2000, 407, 321-326. [CrossRef]

43. Cosgrove, D.J. Plant expansins: Diversity and interactions with plant cell walls. Curr. Opin. Plant Biol. 2015, $25,162-172$. [CrossRef] [PubMed]

44. Burger, A.; Gräfen, I.; Engemann, J.; Niermann, E.; Pieper, M.; Kirchner, O.; Gartemann, K.H.; Eichenlaub, R. Identification of homologues to the pathogenicity factor Pat-1, a putative serine protease of Clavibacter michiganensis subsp. michiganensis. Microbiol. Res. 2005, 160, 417-427. [CrossRef] [PubMed]

45. Stork, I.; Gartemann, K.H.; Burger, A.; Eichenlaub, R. A family of serine proteases of Clavibacter michiganensis subsp. michiganensis: $\operatorname{ch} p$ C plays a role in colonization of the host plant tomato. Mol. Plant Pathol. 2008, 9, 599-608. [CrossRef] [PubMed]

46. Lu, Y.; Hatsugai, N.; Katagiri, F.; Ishimaru, C.A.; Glazebrook, J. Putative serine protease effectors of Clavibacter michiganesis induce a hypersensitive response in the apoplast of Nicotiana species. Mol. Plant Microbe Interact. 2015, 28, 1216-1226. [CrossRef]

47. Hwang, I.S.; Lee, H.M.; Oh, E.J.; Lee, S.; Heu, S.; Oh, C.S. Plasmid composition and the chpG gene determine the virulence level of Clavibacter capsici natural isolates in pepper. Mol. Plant Pathol. 2020, 21, 808-819. [CrossRef]

48. Cantarel, B.L.; Coutinho, P.M.; Rancurel, C.; Bernard, T.; Lombard, V.; Henrissat, B. The carbohydrate-active enzymes database (CAZy): An expert resource for Glycogenomics. Nucleic Acids Res. 2009, 37, 233-238. [CrossRef]

49. Meletzus, D.; Bermphol, A.; Dreier, J.; Eichenlaub, R. Evidence for plasmid-encoded virulence factors in the phytopathogenic bacterium Clavibacter michiganensis subsp. michiganensis NCPPB382. J. Bacteriol. 1993, 175, 2131-2136. [CrossRef]

50. Chalupowicz, L.; Cohen-Kandli, M.; Dror, O.; Eichenlaub, R.; Gartemann, K.H.; Sessa, G.; Barash, I.; Manulis-Sasson, S. Sequential expression of bacterial virulence and plant defense genes during infection of tomato with Clavibacter michiganensis subsp. michiganensis. Phytopathology 2010, 100, 252-261. [CrossRef]

51. Thapa, S.P.; O'Leary, M.; Jacques, M.; Gilbertson, R.L.; Coaker, G. Comparative genomics to develop a specific multiplex PCR assay for detection of Clavibacter michiganensis. Phytopathology 2020, 110, 556-566. [CrossRef]

52. Tancos, M.A.; Lange, H.W.; Smart, C.D. Characterizing the genetic diversity of the Clavibacter michiganensis subsp. michiganensis population in New York. Phytopathology 2015, 105, 169-179. [CrossRef]

53. Lowe-Power, T.M.; Hendrich, C.G.; von Roepenack-Lahaye, E.; Li, B.; Wu, D.; Mitra, R.; Dalsing, B.L.; Ricca, P.; Naidoo, J.; Cook, D.; et al. Metabolomics of tomato xylem sap during bacterial wilt reveals Ralstonia solanacearum produces abundant putrescine, a metabolite that accelerates wilt disease. Environ. Microbiol. 2018, 20, 1330-1349. [CrossRef] 
54. Cellini, A.; Donati, I.; Fiorentini, L.; Vandelle, E.; Polverari, A.; Venturi, V.; Buriani, G.; Vanneste, J.L.; Spinelli, F. N-Acyl Homoserine lactones and Lux Solos regulate social behaviour and virulence of Pseudomonas syringae pv. Actinidiae. Microb. Ecol. 2020, 79, 383-396. [CrossRef] [PubMed]

55. Balaji, V.; Mayrose, M.; Sherf, O.; Jacob-Hirsch, J.; Eichenlaub, R.; Iraki, N.; Manulis-Sasson, S.; Rechavi, G.; Barash, I.; Sessa, G. Tomato transcriptional changes in response to Clavibacter michiganensis subsp. michiganensis reveal a role for ethylene in disease development. Plant Physiol. 2008, 146, 1797-1809. [CrossRef]

56. Yokotani, N.; Hasegawa, Y.; Sato, M.; Hirakawa, H.; Kouzai, Y.; Nishizawa, Y.; Yamamoto, E.; Naito, Y.; Isobe, S. Transcriptome analysis of Clavibacter michiganensis subsp. michiganensis-infected tomatoes: A role of salicylic acid in the host response. BMC. Plant. Biol. 2021, 21, 476. [CrossRef]

57. Melan, M.A.; Dong, X.N.; Endara, M.E. An Arabidopsis thaliana lipoxygenase gene can be induced by pathogens, abscisic acid and methl jasmonate. Plant Physiol. 1993, 101, 441-450. [CrossRef]

58. Hwang, I.S.; Hwang, B.K. The pepper 9-lipoxygenase gene CaLOX1 functions in defense and cell death responses to microbial pathogens. Plant Physiol. 2010, 152, 948-967. [CrossRef]

59. Wiermer, M.; Feys, B.J.; Parker, J.E. Plant immunity: The EDS1 regulatory node. Curr. Opin. Plant Biol. 2005, 8, 383-389. [CrossRef]

60. Joglekar, S.; Suliman, M.; Bartsch, M.; Halder, V.; Maintz, J.; Bautor, J.; Zeier, J.; Parker, J.E.; Kombrink, E. Chemical activation of EDS1/PAD4 signaling leading to pathogen resistance in Arabidopsis. Plant Cell Physiol. 2018, 59, 1592-1607. [CrossRef]

61. Tian, M.; Win, J.; Song, J.; Van der Hoorn, R.; Van der Knaap, E.; Kamoun, S.A. Phytophthora infestans cystatin-like protein targets a novel tomato papain-like apoplastic protease. Plant Physiol. 2007, 143, 364-377. [CrossRef]

62. Li, P.; Zhang, L.; Mo, X.; Ji, H.; Bian, H.; Hu, Y. Aquaporin PIP1; 3 of rice and harpin Hpa1 of bacterial blight pathogen cooperate in a type III effector translocation. J. Exp. Bot. 2019, 70, 3057-3073. [CrossRef]

63. Coaker, G.; Francis, D. Mapping, genetic effects, and epistatic interaction of two bacterial canker resistance QTLs from Lycopersicon hirsutum. Theor. Appl. Genet. 2004, 108, 1047-1055. [CrossRef]

64. Umesha, S. Phenylalanine ammonia lyase activity in tomato seedlings and its relationship to bacterial canker disease resistance Phytoparasitica 2006, 34, 68-71. [CrossRef]

65. Esparza-Araiza, M.J.; Bañuelos-Hernández, B.; Argüello-Astorga, G.R. Evaluation of a SUMO E2 conjugating enzyme involved in resistance to Clavibacter michiganensis subsp. michiganensis in Solanum peruvianum, through a tomato mottle virus VIGS assay. Front. Plant Sci. 2015, 6, 1-11. [CrossRef]

66. Balaji, V.; Smart, C.D. Over-expression of snakin-2 and extensin-like protein genes restricts pathogen invasiveness and enhances tolerance to Clavibacter michiganensis subsp. michiganensis in transgenic tomato (Solanum lycopersicum). Transgenic Res. 2012, 21, 23-37. [CrossRef] [PubMed]

67. Wittmann, J.; Brancato, C.; Berendzen, K.W.; Dreiseikelmann, B. Development of a tomato plant resistant to Clavibacter michiganensis using the endolysin gene of bacteriophage CMP1 as a transgene. Plant Pathol. 2016, 65, 496-502. [CrossRef]

68. Jones, J.D.; Dangl, J.L. The plant immune system. Nature 2006, 444, 323-329. [CrossRef]

69. Thyr, B.D. Resistance to Corynebacterium michiganense measured in six Lycopersicon accessions. Phytopathology 1971, 61, 972-974. [CrossRef]

70. Thyr, B.D. Inheritance of resistance to Corynebacterium michiganense in tomato. Phytopathology 1976, 66, 1116-1119. [CrossRef]

71. Kabelka, E.; Franchino, B.; Francis, D.M. Two loci from Lycopersicon hirsutum LA407 confer resistance to strains of Clavibacter michiganensis subsp. michiganensis. Phytopathology 2002, 92, 504-510. [CrossRef]

72. Van Heusden, A.W.; Koornneef, M.; Voorrips, R.E.; Bruggemann, W.; Pet, G.; Vrielink van Ginkel, R.; Chen, X.; Lindhout, P. Three QTLs from Lycopersicon peruvianum confer a high level of resistance to Clavibacter michiganensis ssp. michiganensis. Theor. Appl. Genet. 1999, 99, 1068-1074. [CrossRef]

73. Sandbrink, J.M.; Vanooijen, J.W.; Purimahua, C.C.; Vrielink, M.; Verkerk, R.; Zabel, P.; Lindhout, P. Localization of genes for bacterial canker resistance in Lycopersicon peruvianum using RFLPs. Theor. Appl. Genet. 1995, 90, 444-450. [CrossRef] [PubMed]

74. Li, Y.L.; Zhang, W.; Zhang, X.Y.; Li, D.Z. Cross breeding of canker-resistance varieties for tomato and identification by SSR molecular markers. Hunan Agric. Sci. 2012, 13, 13-15. (In Chinese)

75. Pereyra-Bistraín, L.I.; Ovando-Vázquez, C.; Rougon-Cardoso, A.; Alpuche-Solís, A.G. Comparative RNA-Seq analysis reveals potentially resistance-related genes in response to bacterial canker of tomato. Genes 2021, 12, 1745. [CrossRef] [PubMed]

76. Gupta, P.K.; Balyan, H.S.; Gautam, T. SWEET genes and TAL effectors for disease resistance in plants:present status and future prospects. Mol. Plant. Pathol. 2021, 22, 1014-1026. [CrossRef]

77. Navathe, S.; Yadav, P.S.; Chand, R.; Mishra, V.K.; Vasistha, N.K.; Meher, P.K.; Joshi, A.K.; Gupta, P.K. ToxA-Tsn1 interaction for spot blotch susceptibility in Indian wheats: An example of inverse gene-for-gene relationship. Plant Dis. 2020, $104,71-81$. [CrossRef]

78. Asai, Y.; Kobayashi, Y.; Kobayashi, I. Increased expression of the tomato SISWEET15 gene during grey mold infection and the possible involvement of the sugar efflux to apoplasm in the disease susceptibility. J. Plant. Pathol. Microbiol. 2016, 7, 1-8. [CrossRef]

79. Shammai, A.; Petreikov, M.; Yeselson, Y.; Faigenboim, A.; Moy-Komemi, M.; Cohen, S.; Cohen, D.; Besaulov, E.; Efrati, A.; Houminer, N.; et al. Natural genetic variation for expression of a SWEET transporter among wild species of Solanum lycopersicum (tomato) determines the hexose composition of ripening tomato fruit. Plant J. 2018, 96, 343-357. [CrossRef] 
80. Yang, X.E.; Long, X.X.; Ni, W.Z.; Ye, Z.Q.; He, Z.L.; Stoffella, P.J.; Calvert, D.V. Assessing copper thresholds for phytotoxicity and potential dietary toxicity in selected vegetable crops. J. Environ. Sci. Health 2002, 37, 625-635. [CrossRef]

81. Baysal, O.; Gursoy, Y.; Ornek, H.; Duru, A. Induction of oxidants in tomato leaves treated with DL-beta-amino butyric acid (BABA) and infected with Clavibacter michiganensis ssp. michiganensis. Eur. J. Plant Pathol. 2005, 112, 361-369. [CrossRef]

82. Baysal, O.; Soylu, E.M.; Soylu, S. Induction of defence-related enzymes and resistance by the plant activator acibenzolar-S-methyl in tomato seedlings against bacterial canker caused by Clavibacter michiganensis ssp. michiganensis. Plant Pathol. 2003, 52, 747-753. [CrossRef]

83. De León, L.; Siverio, F.; López, M.M.; Rodríguez, A. Clavibacter michiganensis subsp. michiganensis, a seedborne tomato pathogen: Healthy seeds are still the goal. Plant Dis. 2011, 95, 1328-1338. [CrossRef] [PubMed] 